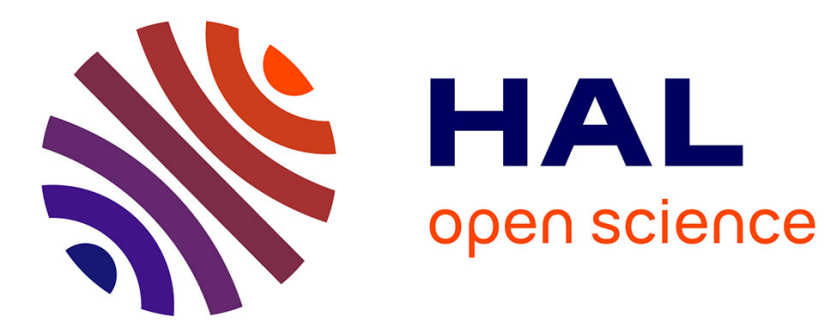

\title{
Europa's interaction with the jovian plasma from hybrid simulation
}

Claire Baskevitch, Baptiste Cecconi, Ronan Modolo

\section{To cite this version:}

Claire Baskevitch, Baptiste Cecconi, Ronan Modolo. Europa's interaction with the jovian plasma from hybrid simulation. Europlanet Science Congress 2021, Sep 2021, Online, France. pp.EPSC2021-617, 10.5194/epsc2021-617 . insu-03562027

\section{HAL Id: insu-03562027 https://hal-insu.archives-ouvertes.fr/insu-03562027}

Submitted on 8 Feb 2022

HAL is a multi-disciplinary open access archive for the deposit and dissemination of scientific research documents, whether they are published or not. The documents may come from teaching and research institutions in France or abroad, or from public or private research centers.
L'archive ouverte pluridisciplinaire HAL, est destinée au dépôt et à la diffusion de documents scientifiques de niveau recherche, publiés ou non, émanant des établissements d'enseignement et de recherche français ou étrangers, des laboratoires publics ou privés. 
EPSC Abstracts

Vol. 15, EPSC2021-617, 2021

https://doi.org/10.5194/epsc2021-617

Europlanet Science Congress 2021

(C) Author(s) 2022. This work is distributed under

the Creative Commons Attribution 4.0 License.

\section{Europa's interaction with the jovian plasma from hybrid simulation}

Claire-Alexandra Baskevitch ${ }^{1,2}$, Baptiste Cecconi ${ }^{2}$, and Ronan Modolo ${ }^{1}$

${ }^{1}$ UMR8190, LATMOS, CNRS, Sorbonne Université, 75252 Paris, France

${ }^{2}$ UMR8109, LESIA Observatoire de Paris, Université PSL, CNRS, Sorbonne Université, Université de Paris, 92195 Meudon, France

Galilean moons are embedded in Jupiter's giant magnetosphere. The jovian plasma particles interact with the atmosphere of the moons, exchanging momentum and energy, and generate different phenoma such as aurora, electric current, etc.

The exploration of the Galilean moons, and in particular Ganymede and Europa considered as potential habitats, are listed among the main objectives of the ESA JUpiter ICy moon Explorer mission. In preparation of future observations, a simulation effort is conducted to describe the Europa moon-magnetosphere system as well as a study of radio wave propagation in the environments of Ganymede and Europa using a ray tracing code.

LatHyS is a hybrid 3D, multi-species and parallel simulation model which is based on a kinetic description of ions and a fluid description of electrons. The model is based on the CAM-CL algorithm that Alan Matthews ${ }^{1}$ outlined in 1994. It allows to describe the interaction between the jovian plasma and the moon environments. As Ganymede's environment has already been implemented, we propose to enrich the model by completing it with Europa's - jovian plasma interaction and to optimize it in order to improve the accuracy of the results.

Artemis-P, developed by Gautier ${ }^{2}$ in 2013, is a ray tracing code that calculates the trajectory of waves through a given environment. Planetary environments are anisotropic and inhomogeneous, so that radio waves can undergo refraction, reflection, scattering, diffraction, interference, etc. between the source and the detector. The ray tracing methods allow to treat the refraction and reflection phenomena at large scales compared to the wavelength. The proposed work is to adjust this program to the environments of Ganymede and Europa using data from LatHyS simulations.

\section{Références :}

${ }^{1}$ Alan P. Matthews, Current Advance Method and Cyclic Leapfrog for 2D Multispecies Hybrid Plasma Simulations, Journal of Computational Physics, Volume 112, Issue 1, 1994, Pages 102-116, ISSN 0021-9991, https://doi.org/10.1006/jcph.1994.1084.

2 Anne-Lise Gautier. Étude de la propagation des ondes radio dans les environnements planétaires. Planétologie et astrophysique de la terre [astro-ph.EP]. Observatoire de Paris, 2013. Français. tel-01145651v2 